NEW SCOTS? EASTERN EUROPEAN YOUNG PEOPLE'S FEELINGS OF BELONGING

AND NATIONAL IDENTITY IN SCOTLAND POST-BREXIT

\author{
ACCEPTED MANUSCRIPT, SCOTTISH AFFAIRS, MAY 2020
}

DANIELA SIME, UNIVERSITY OF STRATHCLYDE

Contact: daniela.sime@strath.ac.uk

\begin{abstract}
This article examines the impact of Brexit on young people aged 12-18 who had moved to Scotland from Central and Eastern Europe. It draws on empirical data collected with over 250 young people who contributed to an online survey and focus groups between 2016-2018, immediately after the Brexit Referendum took place. The paper examines young people's feelings of national identity and how their sense of belonging has been impacted by Brexit. The key findings reveal that factors such as their everyday experiences of racism and xenophobia and perceptions of what other people, often their friends, might think about who gets to belong were identified as significant to the identities young migrants felt able to claim. While many young people expressed a strong sense of belonging in the UK as a whole and over half said they were feeling Scottish, access to a Scottish national identity seems to be restricted and often denied to them. At the same time, many felt able to occupy the national identity of their country of birth or claim hyphenated identities that included Scottishness and a European identity. In the context of Brexit, this poses a challenge for making New Scots feel like they belong in Scotland, as many may now decide to review their plans to remain in Scotland longterm if their rights change.
\end{abstract}

KEYWORDS: NATIONAL IDENTITY; EASTERN EUROPEAN MIGRANTS; MIGRATION; YOUNG PEOPLE; BELONGING; NEW SCOTS; BREXIT

\title{
Bio and acknowledgements
}

Daniela Sime is Professor of Youth, Migration and Social Justice in the School of Social Work \& Social Policy at the University of Strathclyde. She was project lead for the study which formed the basis of this article, entitled 'Here to stay? Identity, belonging and citizenship among Eastern European settled migrant children in the UK (a decade after the EU Enlargement'), which was funded by the Economic and Social Research Council, grant number: ES/M011038/1. The author would like to thank the young people and the researchers who have contributed to the project and also the editorial team of the Special Issue for valuable comments on an earlier version of this article. 


\section{INTRODUCTION}

The issue of immigration has become increasingly politicised since the Brexit Referendum in 2016, although many have argued that the Holyrood Government has managed to promote a more welcoming and inclusive discourse north of the border (Hepburn and Rosie, 2014). Over the last two decades, the Scottish Government's stance on immigration has been one of openness and recognition of its financial and demographic benefits, with 'New Scots' seen as part of an inclusive Scottish national identity (Devine and McCarty, 2018). Political leaders such as Nicola Sturgeon have spoken openly about support for migrants to settle in Scotland and the Government's intention to continue to campaign for devolved immigration powers, to allow Scotland to implement an immigration policy better suited for its economic needs. Some assume this would likely be a less restrictive immigration policy than the rest of the United Kingdom, to help address Scotland's demographic challenges (McCollum et al., 2014). This inevitably has been contrasted with political discourses at Westminster and the debates which led to the Brexit Referendum, where successive Government leaders have pledged to reduce net migration and immigration debates have taken place in often alarmist and pejorative terms of 'threats' immigrants pose to jobs, public services, crime rates and community cohesion.

Immigration was a significant factor in the 2016 EU Referendum and a key issue during the Brexit debate. The popular slogan of the Brexit campaign - 'Take back control'- was seen by some voters as meaning more control over immigration and borders and restricting freedom of movement from the EU countries. Evidence shows that levels of opposition to migration remain high and less than 1 in 5 people would want an increase in immigration numbers, although a recent softening in attitudes has been reported (Blinder and Richards, 2020). While in 2015/16 immigration was perceived to be 'one of the most important issues' facing the British public by $48 \%$ respondents, by 2020 , the public became more concerned about 'health' (66\%) and 'the economy' $(57 \%)$ as the Covid-19 pandemic unravelled and immigration was mentioned by only $16 \%$ of the people surveyed (YouGov, 2020). Public attitudes to immigration in Scotland have been described anecdotally as less hostile than elsewhere in the UK, perhaps due to a combination of positive political discourses, a reliance on immigration for population growth and relatively low immigration levels. Yet, these attitudes are not too different from those in England and Wales, suggesting a disjunction between the pro-migration political rhetoric and anti-immigration sentiments at population level. While far more people in Scotland think that immigration is good for the economy (46\%) than those who think it is bad (17\%), the figures are similar with views expressed in other regions of the UK (Curtice and Montagu, 2017). In a 2013 survey, close to half of people surveyed in Scotland saw increased numbers of ethnic minority groups as a threat to Scotland's identity (Scottish Social Attitudes, 2013). At the same time, a majority result of Remain votes in the EU Referendum (at $62 \%$ in Scotland) has boosted the Scottish Government's narrative that Scotland is, in the main, pro-Europe and implicitly in favour of freedom of movement. Yet, evidence suggests that opposition to immigration may be relatively high amongst 'the very people who feel most Scottish and are most in favour of constitutional change in Scotland' (McCollum et al., 2014: 95). 
There are currently about 238,000 EU nationals living in Scotland, representing 63\% of Scotland's non-British population (National Records of Scotland, 2019), where Polish nationals, at 97,000 (+/$12 \%)$, are the most common non-British nationality in Scotland. Nationals of EU member states are likely to be impacted considerably by the United Kingdom's decision to leave the European Union and the cumulative effects of a predicted recession post-Covid 19. Some of these effects are already manifest, such as risks to migrants' employment and housing rights, uncertainty over their immigration status and welfare rights, and concerns over family reunion rights given the end of freedom of movement (Hepburn, 2020). While other studies (Guma and Dafydd Jones, 2019) have mainly documented the concerns and anxieties of adult migrants, this paper draws on findings from research carried out with young people aged 12-18 who arrived in the UK as migrant children from Central and Eastern Europe (CEE) after the enlargement of the European Union post-2004. The project, carried out between April 2016 and January 2019, covering both the Referendum and the post-Referendum period, explored young people's feelings of identity and belonging in the UK and plans for future in the context of the Brexit negotiations (Tyrrell et al., 2019; Sime et al., 2020). The findings present the first analysis since the Brexit Referendum of how young EU migrants navigate multiple national identities and find it difficult to claim Scottishness, despite its proclaimed inclusive nature and the proEuropeanism which have become the cornerstone of progressive politics in Scotland. It also examines the extent to which these identities and nationalisms are perceived as inclusive, and also documents young people's everyday struggles to assert their belonging in Scotland despite their ongoing racialisation (Fox et al., 2012).

The article starts with a review of what we know from existing research on Scottish national identity and minority ethnic groups. The data I draw on come from a sub-sample of a bigger UK-wide cohort and includes 190 responses from young people living in Scotland who completed an online survey and eleven focus groups with 61 young people of Eastern European origin. I analyse how the participants engaged with issues of national identity and fluidly construct their identities, depending on what they perceived as available and desirable identities to claim. Before I go on to discuss the findings, I review existing evidence on Scottishness and the research on Scottish identity carried out with minority groups and outline the methods of data collection and analysis.

\section{A COUNTRY FOR NEW SCOTS? SCOTTISHNESS AS POSSIBLE IDENTITY FOR MIGRANT YOUTH}

Debates on Scotland's future relationship with the rest of UK and Europe, political attitudes and voting behaviours are increasingly driven by considerations of national identity and what Scottishness means in relation to other identities available to migrants in the UK. The upsurge of nationalist sentiment in Scotland and ongoing debates over its constitutional future since the Independence Referendum in 2014 and the EU Referendum in 2016 are clearly shaping a new landscape in relation to Scotland's place in Europe. Many have argued that the SNP-led government has managed to promote a more 
progressive and inclusive, 'civic' nationalism (McCollum et al., 2014), with a pro-immigration stance that would be influencing immigration policy in case of constitutional change. Indeed, over the last decade, the SNP-led government has taken a positive stance on immigration, with campaigns aimed at attracting 'New Scots' to come and live in Scotland. Emejulu (2013) has argued that by constructing England and Englishness as 'a repository of various negative aspects of culture, politics and society in Scotland' (p. 44), the idea of Scottishness becomes secure and adaptable to further inclusions, while presented as a superior form of identity to the English one. This also means that spaces for new types of ethnic minorities can be created within the Scottish identity space, where 'the Other' is represented by the English and England. Scotland is thus presented as empathic to other potentially oppressed groups, given the history of being oppressed by an English rule. This inclusive form of civic national identity promoted for decades may also explain why Scotland has not seen a rise in populist, xenophobic politics, unlike other European countries (e.g. Austria, Hungary, Poland, Spain).

A shared national identity is often seen as a sign of social cohesion; similarly, a feeling of being excluded as an individual or group can have detrimental consequences for the societies in which those feeling marginalised live. There is some evidence that, in Scotland, certain minority ethnic groups feel a sense of national identity and pride when it comes to their Scottishness (Emejulu, 2013; Bonino, 2015) and do not seem to experience a tension in using their self-selected hyphenated identities, such as Scottish-Pakistani or Scottish-Muslim. However, this identification is not homogenous across minority ethnic groups. While large minorities such as Pakistani Muslim, Indian and Other Asian show higher rates of sub-state identification in Scotland than in other nations of the UK, Scottish identification seems less strong among White Polish or White Other, Indian Hindus, Chinese, Black African Christians (Bond, 2016). Overall, among all minority groups, Scottish identification is much lower than among the White majority, posing under question the claims that a multicultural nationalist project is succeeding in Scotland. Bond's analysis (2016), using Census 2011 data, also showed that those who have migrated to Scotland are less likely to feel 'Scottish' than those born here and Scottishness does not necessarily emerge as an identity or as part of a hyphenated identity even with long-term residence. Research on census data is very useful in this sense, as it allows for comparisons between groups, although limitations exist. For example, the Census 2011 included only one question on national identity and limited young migrants' agency and voice, as all data on children and young people under 16 was collected by proxy, through adults. This paper aims thus to address the lack of data on young migrants' sense of national identity, in the context of intensified debates on migration, migrants' place in Scotland and Scotland's potential constitutional change. 


\section{METHODOLOGY}

The study adopted a methodological design which focussed on maximising the input of young people in the choice of methods, data collection and dissemination activities. Drawing on the new sociology of childhood and youth (James and Prout, 2014), which acknowledges the centrality of young people's voice in research about their lives, the methodology elicited data through the direct involvement of young people. Between October 2016-April 2017, we gathered the opinions and experiences of young people from Central and Eastern Europe who had migrated to the UK as children on a range of issues, including feelings of belonging, participation in communities, access to services, experiences of prejudice and exclusion, their relationships, well-being and plans for future. An online survey was completed by over 1,100 young people. In Scotland, 190 young people took the survey, of which $45 \%$ were in the 12-15 age group and 55\% were 16-18; respondents lived mainly in urban areas (78\%). Only the data from this sub-sample are used here. While the majority $(72 \%, n=137)$ were born in Poland, there were 9 other nationalities given (Lithuanian, Latvian, Romanian, Bulgarian, Czech, Estonian, Hungarian, Slovakia, Ukranian). As EU nationals were exercising their freedom of movement in the UK, only a very small proportion $(7 \%)$ had dual or triple nationality $(n=14)$ and the rest retained the nationality of their country of birth.

After the survey, between May-June 2017, we organised eleven focus groups with 61 young people (30 female, 31 male) in schools across Scotland and carried out in-depth case studies with 9 young people (6 female, 3 male) and their families. The focus groups discussed issues of identity and belonging in the context of Brexit, access to services and perceptions of likely impact of Brexit on their families. In the focus groups and family visits, we used an interactive facilitation kit (Ketso, www.ketso.com), which allows participants to write or draw their ideas on colour-coded cards, before they engage in group conversations and share their ideas under pre-established themes. In presenting the data, I use descriptive statics for the quantitative data, which limits the potential for generalisation from this sample, and a thematic approach for the qualitative data. The project benefited from guidance from a Youth Advisory Group, who were involved from design to dissemination, including the production of an arts exhibition at Glasgow's Tramway Museum. It received ethical approval from the author's institution and ethical issues of consent, anonymity and right to withdraw were observed at all stages, in addition to ensuring participants were not at risk of harm. All participants' names have been changed.

\section{FEELINGS OF (NON)BELONGING}

As this was a UK-wide study, young people were asked if they felt they belonged in the United Kingdom. The vast majority (87\%) expressed a feeling of belonging in the UK and only $4 \%$ said that they 'definitely' did not feel that they belonged in the UK. At the same time, young people remained unsure whether they will be able to continue to live in the UK and $85 \%$ did not feel hopeful about Britain's decision to leave the EU. Close to half (43\%) said they felt 'worried' about their future post- 
Brexit (see Tyrrell et al., 2019). Young people were aware of the key role that the anti-immigration rhetoric had played in the Brexit Referendum:

Josef: Don't you think most of people who voted for Brexit didn't actually understand what it's about? They all just thought, "we vote Brexit, we're going to get rid of all the immigrants".

That's what they thought.

Interviewer: So do you think that was the main reason that people voted for Brexit? Josef: That is the main reason. Let's be honest. (Focus Group)

In the same group, Josef and Marek, both Polish, talk about the risk to EU nationals' right to remain in the UK post-Brexit and threats of deportation, although at the time of the interviews, EU nationals were exercising their freedom of movement right and were not subject to immigration controls:

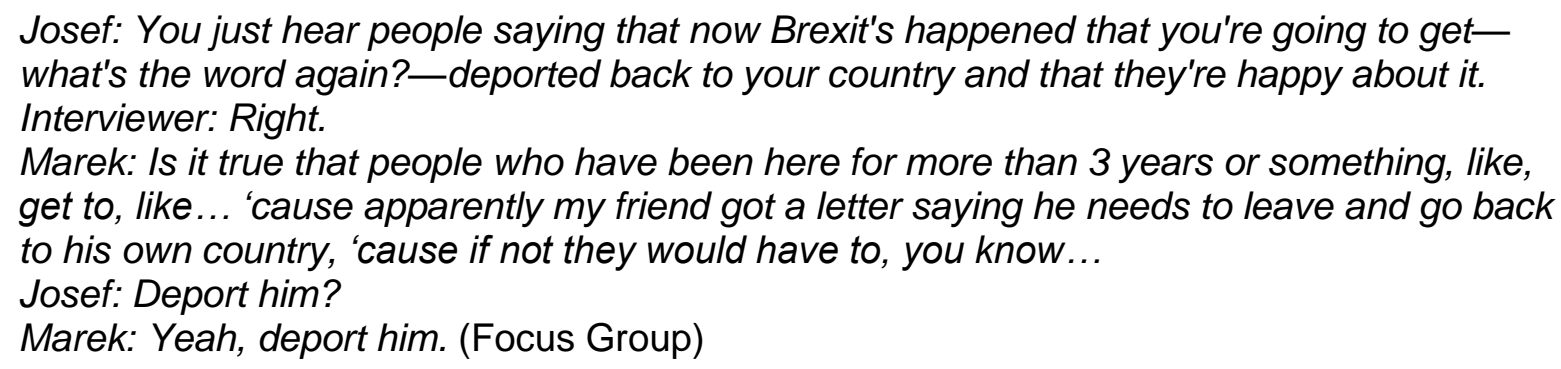

In the online survey, young people also described incidents of cultural racism, xenophobia and microaggressions they experienced mainly in school, but also in public places, which made them think they were not welcome in Scotland, despite their feelings of belonging here. These experiences of everyday individual or institutionalised forms of prejudice-based discrimination and racism went largely unreported and young people often brushed them off:

I have experienced racism in school, people telling me to go back to my own country and telling me I don't belong here, also people making fun of me because I'm not from here.

Got called white trash, got excluded with other Polish friends because we aren't Scottish etc. Made fun of my accent (I moved from England to Scotland).

During a football match, a gang of Scottish guys (aged 16-18) came and assaulted my friends with wrenches, pipes and hammers for being Polish.

Someone drew a Swastika on my house and wrote go back to your country and stop stealing jobs. (Survey respondents)

Many of these incidents involved young people being othered through markers of difference other than their skin colour, such as their accent or nationality. These showed the tension young Europeans perceived between their sense of belonging in the UK and their experiences of victimisation. As many of these incidents happened in schools, young people's sense of security and belonging to the schools as communities of learning and cohesion were also altered. The survey data showed that those young people who believed their school was supportive of Central and Eastern European young people were 
more likely to feel a sense of belonging to the UK and were more likely to want to remain long-term, even after Brexit. Overall, a stronger feeling of belonging to the UK was associated with higher levels of satisfaction with their lives in the UK, which points to clear policy implications for ensuring that the narrative of welcoming Scotland is translated into inclusive practices at community level. The evidence suggests a disjoint between the inclusive political rhetoric and new ethnic minorities' everyday experiences, reflected also in the public attitudes to migration.

\section{IDENTITY STRUGGLES- NAVIGATING MULTIPLE IDENTITIES}

When analysing young people's feelings of identity and how they thought of themselves in relation to national identities, the identity struggles most young people were experiencing became apparent across all datasets. In the online survey, when asked 'What do you feel is your national identity?', a majority of young people identified first and foremost with their country of birth, although many had lived in the UK for many years. Out of 190 responses, just over half $(53 \%, n=101)$ gave their national identity as that of their country of birth (or region) and about 40 per cent $(n=76)$ gave a hyphenated identity. A quarter of all respondents $(n=46)$ included 'Scottishness' in their hyphenated identities or said they felt Scottish (see Table 1), and another quarter included Britishness or Englishness as part of their national identity, although length of stay did not differ significantly between these three groups. Only $7 \%$ of all the whole sample said they had a British passport or dual nationality, including British, and given EU nationals were free to exercise their freedom of movement at the time of the study, many did not see the need to acquire British citizenship or found its associated costs (at around $£ 1,330$ per person) prohibitive. 


\begin{tabular}{|c|c|c|c|}
\hline Country of birth & $\begin{array}{l}\text { Single national } \\
\text { identity } \\
\text { country/region of } \\
\text { birth }\end{array}$ & $\begin{array}{l}\text { Hyphenated identity } \\
\text { or Scottish identity }\end{array}$ & $\begin{array}{l}\text { Hyphenated British or } \\
\text { English identity, only } \\
\text { British, or not sure }\end{array}$ \\
\hline $\begin{array}{l}\text { Poland } \\
(n=137)\end{array}$ & Polish $(n=73)$ & $\begin{array}{l}\text { Polish-Scottish }(n=19) \\
\text { Scottish-Polish }(n=3) \\
\text { Scottish }(n=3)\end{array}$ & $\begin{array}{l}\text { Polish-British }(n=35) \\
\text { British }(n=3) \\
\text { Don't know }(n=1)\end{array}$ \\
\hline $\begin{array}{l}\text { Lithuania } \\
(\mathrm{n}=13)\end{array}$ & $\begin{array}{l}\text { Lithuanian }(n=1) \\
\text { Russian }(n=4)\end{array}$ & $\begin{array}{l}\text { Lithuanian-Scottish }(n=1) \\
\text { Lithuanian-Scottish-British } \\
(n=2) \\
\text { Scottish-Lithuanian }(n=1) \\
\text { Scottish }(n=2)\end{array}$ & $\begin{array}{l}\text { Lithuanian-British }(n=1) \\
\text { Lithuanian- English }(n=1)\end{array}$ \\
\hline $\begin{array}{l}\text { Latvia } \\
(\mathrm{n}=10)\end{array}$ & $\begin{array}{l}\text { Latvian }(n=4) \\
\text { European }(n=1)\end{array}$ & $\begin{array}{l}\text { Latvian-Scottish }(n=3) \\
\text { Scottish }(n=1)\end{array}$ & Latvian-British $(\mathrm{n}=1)$ \\
\hline Bulgaria $(n=6)$ & Bulgarian $(n=3)$ & Bulgarian-Scottish $(n=3)$ & \\
\hline Romania $(n=6)$ & $\begin{array}{l}\text { Romanian }(n=4) \\
\text { Hungarian }(n=1)\end{array}$ & Scottish $(n=1)$ & \\
\hline Hungary $(n=4)$ & $\begin{array}{l}\text { Hungarian }(n=2) \\
\text { European }(n=1)\end{array}$ & Hungarian-Scottish $(n=1)$ & \\
\hline Czech R $(n=4)$ & & Czech-Scottish $(n=3)$ & Czech-English $(\mathrm{n}=1)$ \\
\hline Estonia $(n=4)$ & $\begin{array}{l}\text { Estonian }(\mathrm{n}=2) \\
\text { Russian }(\mathrm{n}=2)\end{array}$ & & \\
\hline Slovakia $(n=3)$ & Slovak $(\mathrm{n}=3)$ & & \\
\hline $\begin{array}{l}\text { Russia } \\
\text { Ukraine }(n=3)\end{array}$ & & $\begin{array}{l}\text { Scottish-Russian }(n=1) \\
\text { Scottish }(n=2)\end{array}$ & \\
\hline Total $=190$ & $\begin{array}{l}\text { Total= } 101 \\
53 \%\end{array}$ & $\begin{array}{l}\text { Total }=46 \\
24 \%\end{array}$ & $\begin{array}{l}\text { Total }=43 \\
23 \%\end{array}$ \\
\hline $\begin{array}{l}\text { Average length } \\
\text { of living in UK } \\
\text { (years) }\end{array}$ & 8.12 & 8.72 & 8.92 \\
\hline
\end{tabular}

Table 1. Country of birth and national identity given by participants in survey $(n=190)$

When asked if they felt Scottish, British, English or European, in a subsequent 'yes/no' question, just over half said they felt Scottish (51\%), and a smaller proportion said they felt British (37\%) or English (11\%). These results are comparable with data from a Scottish-born youth sample, in which $53 \%$ of the respondents identified as 'Scottish, not British' or 'more Scottish than British' and 39\% said they felt 'equally Scottish and British' (Eichhorn et al., 2014). In many respects, this could be seen as an indicator of young people's fluid identity as 'New Scots', given just over half of our sample said they felt Scottish when asked a direct question, yet only $24 \%$ identified Scottishness as their national identity when asked to describe what they felt their national identity was (see Table 1). Combined with young people's sense of belonging to the UK which was high (87\%), this may suggest that young migrants may present a group more likely to engage with the inclusive multiculturalism project of Scotland. 


\begin{tabular}{|l|l|l|l|l|}
\hline Do you feel... & Yes & No & Don't know & $\begin{array}{l}\text { Total } \\
\text { responses }\end{array}$ \\
\hline Scottish & $51 \%(n=80)$ & $32 \%(n=50)$ & $17 \%(n=26)$ & $N=156$ \\
\hline English & $11 \%(n=18)$ & $77 \%(n=120)$ & $12 \%(n=19)$ & $N=157$ \\
\hline British & $37 \%(n=58)$ & $47 \%(n=75)$ & $16 \%(n=26)$ & $N=159$ \\
\hline European & $90 \%(n=148)$ & $4 \%(n=6)$ & $7 \%(n=11)$ & $N=165$ \\
\hline
\end{tabular}

Table 2. Young people's identification with the regions of the UK and Europe

However, in the focus groups and family case studies, young people felt they could not claim a Scottish identity. While they were keen to emphasise their sense of belonging in Scotland, claiming national identity was seen as more problematic. In addition, the threat to their freedom of movement post-Brexit and the risk of losing the opportunity to travel and study in Europe, made many less likely to see themselves as committing to remain in Scotland long-term and hence less likely to claim Scottishness:

Brexit has made me question my place in this country, and whether I have a future here (which I most definitely do want). Although being Polish is a big part of my identity, I don't feel that I ever want to permanently live there again. In fact, I can't picture myself living permanently anywhere, which is probably caused by moving to and from Scotland more than once-I have a very unclear and distorted sense of identity and belonging. (Survey respondent, Female, 17, Polish)

I feel like this is my home, but I'm worried that I won't be able to go freely to my birth country, I plan on finishing my education and travel Europe and I think it's gonna be more difficult now. I would like to live in the U.K. or Canada in the future. (Survey respondent, Female, 17, Polish)

Many felt they could never claim to be Scottish, no matter how long they had lived in the UK and that any claims to Scottishness would be denied to them by their Scottish-born friends or neighbours, because of markers of difference, such as their accent or them not being born in Scotland. They seemed clear that a Scottish identity was not available and length of residence would not make a difference. These young people felt that one's place of birth and citizenship ties one to their nationality and remains forever part of their national identity:

Interviewer: When you think about your nationality, do you think of yourself, like, would you say "I'm Scottish"? Would you say "I'm British"? Would you say "I'm European"? Would you say "I'm Polish"?

Josef: I'm Polish.

Marek: We are Polish.

Interviewer: Polish, yeah. Joanna?

Joanna: Polish. 
Interviewer: Or would you ever say Polish-Scottish?

Joannna: No.

Interviewer: Not really? Always Polish.

Marek: No matter what, I'm still Polish. I've been born in Poland and brought up in Poland. Josef: My parents are Polish, so I'm Polish. (Focus group)

In a minority of cases, young people felt that the rapid increase in immigration was a threat to Britain's identity and that made it more difficult for anyone, including British nationals, to maintain a sense of national identity:

If I could have voted at the time [in the Brexit Referendum], I would have voted Leave. I could never feel fully British or Scottish because your nationality is in your blood, not in the language you speak - although Europeans can mix pretty well. Furthermore, the amount of immigration to the United Kingdom is insane, I can't imagine how anyone could feel a sense of nationality here - which, I believe, is crucial for a peoples' survival - because it's been diluted so heavily that being British has no meaning anymore. (Survey Respondent, Male, 18, Polish)

In summary, although some of the young people reported a hyphenated identity in the survey (PolishScottish, Scottish-Lithuanian, Lithuanian-Scottish-British etc.), the majority did not think they could reasonably and confidently claim a Scottish or British identity and seemed to experience pressure mainly from their peers, but also reflecting media discourses on nationalism and who gets to belong. This is in contrast with findings from Emejulu's study (2013) and others with Scottish Pakistani groups, where adults who were either born in Pakistan and had migrated to Scotland or were born in Scotland to Pakistani families seemed to experience no tension in relation to claiming a hyphenated identity ('Scottish-Pakistani or 'Scottish-Muslim'). Hussain and Miller (2006) argued that because Scottish Pakistanis' primary identity is cultural, the adoption of Scottishness in their ethnic identity is more salient. Scottish identification is less strong among other ethno-religious groups, including Polish (Bond, 2016). This may suggest that a Scottish identity is not perceived as straightforwardly inclusive by all minority groups, despite evidence of a politics of multicultural nationalism in Scotland (Hussain and Miller 2006, Hunter and Meer, 2018).

The European identity was, by contrast, perceived as more accessible, through young people's citizenship and membership of the EU. In the sample, $90 \%$ of the respondents in Scotland said they felt European, clearly indicating the saliency of a European identity as more available and uncontested. This finding shows that participants clearly felt a strong sense of connection and belonging to Europe, with many saying that a European identity will always be part of who they are and how they see their place in the world. For the majority, feeling European and also having a sense of belonging to the UK and Scotland were entirely compatible:

I feel very connected to Europe and a European culture. There has been some concern regarding whether I want to stay in this country in the future due to the political changes 
happening in the UK. I am considering moving to the EU after finishing university, despite the fact I enjoy living in this country. (Survey respondent, Male, 18, Latvia)

When asked about a sense of belonging to their local neighbourhood, only $13 \%$ said that they 'always' felt they belonged in their local neighbourhood, and 30\% said that they 'mostly' did. In addition, 1 in 5 said that they 'never' or 'mostly' felt that they did not belong. The sense of not belonging to their neighbourhoods was strongly linked to young people's perceptions of their neighbours as being prejudiced against Eastern European migrants or not. This suggests that developing a sense of local neighbourhood belonging has been challenging for some of the young Europeans, perhaps more so than developing a feeling of belonging to Britain.

Some of the young people commented that they had experienced increased racism and xenophobia in their neighbourhoods since the Brexit Referendum and that this had changed the way they felt about their areas. This can be a factor in young people's readiness to adopt a Scottish identity, if perceptions at local of attitudes to 'New Scots' are negative. Even among young people who moved to Scotland as children, the feeling of national belonging appeared to have been disrupted by Britain's decision to leave the EU. While those living in Scotland were more likely to say 'they felt Scottish' than those in England saying they 'felt English', overall, young people felt that Brexit was a rejection of their plans to settle and make a home in Scotland. For some, this was also a reason to express views in favour of Scotland's plans to become independent and rejoin the European Union:

I would like Scotland to leave the U.K., and I'd like it to stay a part of the European Union. Although I don't think my opinion is as valid as someone who plans to stay in Scotland or the UK since I plan to travel and explore where else I could end up living, I'm thinking I'll one day move to Scandinavia or New Zealand. (Survey Respondent, Female, 17, Czech)

I feel like I belong as a part of Scotland, but I don't feel part of Britain as a whole. Scotland has been extremely welcoming and accepting, but English and immigrants of other nationalities have been much more intolerant as well as the younger generations in Scotland. I plan to study abroad, but will most likely have to study in Scotland to avoid tuition fees, so with Brexit looming I'm a bit apprehensive as to how it will affect my higher education. (Survey Respondent, Female, 15, Latvian-Scottish)

Young people talked about how they incorporated Scottish cuisine, cultures and traditions into their family life and their everyday practices. They were keen to talk about the aspects of the Scottish culture their families embraced and loved, such as customs and traditions, food and drink, and places they loved to visit around Scotland. These traditions had been adopted by families over years and were often observed in parallel with customs and traditions families maintained from their country of migration. 
Vladislaw: We buy just British products, but we prepare [the food] in Polish ways. And also we have like British, Scottish meals, like haggis and the tatties. And em, sometimes for breakfast we have like Lorne sausage.

Amelia My mum, she loves nature, she loves Scotland-she likes the culture and the history and the music.

Interviewer: What is it about the Scottish culture and history that you like?

Amelia: $\quad$ Like the kinda traditional clothes and stuff, like you know like Caledonian, you know how they do the drums and that kinda music. My mum she likes...the bagpipes. (Focus group)

However, this appeared to be an intermittent, selective engagement with Scottishness and aspects of the Scottish culture, which many felt they should respect and be aware of given they were now living in Scotland. This did not mean that they could see themselves as adopting or developing a hyphenated ethnic identity in time, although the majority anticipated they were likely to remain in Scotland in the future. While the devolved Scottish government has pursued over the last decade a cultural and institutional context which is pro-immigration and inclusive, there are aspects of young people's everyday life that seem to make them less likely than others, more established minorities to adopt Scottishness as part of their identity. One potential explanation is that young people consistently reported incidents of discrimination and racism, with over two thirds of the survey sample $(70 \%)$ saying they had been victims of occasional or regular prejudice-based bullying and discrimination, mainly in schools, but also in their local communities.

Nadia: $\quad$ There was a lot of racism. But now, like, it's kind of gone now. And I don't really pay attention to it, cause I think it's kind of stupid.

Sylvia: $\quad$ Yeah, you kind of learn more as time goes on.

Denis: $\quad$ Yeah, everyone's used to you by now. (Focus group)

While $65 \%$ of the young people said they were satisfied with their school and felt schools were 'fairly' or 'very' supportive of Eastern Europeans, many commented on how schools made regular attempts to constrain young people's cultural and ethnic identities, by denying markers of identities other than Scottish in the school.

Sylvia: $\quad$ Yeah, 'cause the teachers are saying, like, in class that we're not supposed to speak in our own language. Cause they would think -

Donna: It was me and my friend, we were talking the language in classes and they said, like a teacher came up to us and said that we can't do that cause other people will think that we're talking about them...

Amelie: $\quad$ Yeah, yeah.

Nadia: $\quad$ Yeah, we got into trouble for speaking in Polish in primary.

Sylvia: $\quad$ And we had to eat lunch in separate rooms. 
Nadia: $\quad$ Like, we weren't allowed to... we got, like, separated completely because we were speaking in, like, our native language. (Focus Group)

The evidence presented suggests that some opportunities exist for new migrants to connect with the identity of Scottishness in time, especially when they have moved to Scotland from a young age. However, everyday practices of exclusion and micro-aggressions, as well as racist and xenophobic incidents, are threating the development of a Scottish or blended national identity for this group. As other research on minorities and national identity has demonstrated (Emejulu, 2013; Bonino, 2015), a sense of national identity and feelings of belonging to a place are closely connected. The narrative of a Scottish exceptionalism needs to be qualified, in light of evidence presented here (see also Davidson et al., 2018) that Scotland does not have a problem with racism and anti-immigration feelings. Although most young people feel that a sense of Scottishness, European and Eastern European identities can be negotiated without significant tension, it appears that the extent to which they are able to develop a sense Scottishness and a Scottish identity depends on several factors. These include feelings of belonging to their schools and communities, perceptions of attitudes from locals and security over their long-term residence. In the context of Brexit, a European identity becomes more salient and stable, and as young people find themselves uncertain about their rights to remain in Britain, they imagine their future open in terms of moving elsewhere (see Sime et al., 2020). This process of belonging and identifying with the nation is made more difficult by young people's everyday experiences of being othered, racism and xenophobia and the lack of political representation, which was seen by many as one of the reasons why the Brexit process and its aftermath was a significant risk to EU nationals' rights and security.

\section{CONCLUSION}

In this paper, I have aimed to provide an analysis of the processes of identity negotiation young Eastern Europeans are going through in the context of Brexit, how they understand their multiple identities and the important role their sense of belonging plays in defining their national identities. Young EU-born nationals settled in Scotland feel less able to make claims to a Scottish identity, despite a strong sense of belonging and long-term residence, while their sense of a European identity is much stronger. In the context of Brexit, this may be due to a perception of a European identity as more inclusive and readily available to them, given current anti-immigration discourses in Britain, ongoing debates over national identity in Scotland and migrants' everyday experiences of marginalisation. Many young people feel that their sense of belonging to Scotland and the rest of the UK, and their future life plans, were now uncertain because of Brexit. Young Eastern Europeans who experience racism are less likely to feel a strong sense of belonging to their new country of residence and their local neighbourhood. The majority of the young people in the survey and focus groups said they had experienced racism, xenophobia and prejudice-based bullying or harassment and this posed a tension between their public selves, where young people did not feel they could have a claim to 
Scottishness, and the private, personal selves, where more than half said they felt Scottish. Experiencing racism also appeared to lower young people's feelings of satisfaction with their life in the UK and was likely to make some think about future destinations where they could move to after finishing school or university.

While many young people expressed a strong sense of belonging to Scotland and the UK as a whole, access to a Scottish national identity seems to be restricted and often denied for new migrants. In the context of Brexit, this poses a challenge for young migrants, why may review their plans to remain in Scotland long-term if their rights change. This is despite considerable efforts from Scotland's devolved government to promote an inclusive Scottish national identity and present a more pro-European and pro-immigration nationalism in Scotland. It remains to be seen how continued plans to push for constitutional change and devolved immigration powers are harmonised in the context of ongoing exclusionary practices in communities and anti-immigration views often expressed by many of those most committed to the independence project. This may see the SNP-led Government faced with a significant political challenge, as they aim to appeal to both independence-favouring Scots, some of whom are resistant to immigration, and the 'New Scots' - migrants they need to attract to secure Scotland's prosperity, economy and tackle its demographic challenge.

\section{References}

Blinder, S. and Richards, L. (2020) UK Public Opinion toward Immigration: Overall attitudes and levels of concern, University of Oxford: The Migration Observatory. Online at: https://migrationobservatory.ox.ac.uk/resources/briefings/uk-public-opinion-toward-immigrationoverall-attitudes-and-level-of-concern/

Bond, R. (2016) Multicultural nationalism? National identities among minority groups in Scotland's census, Journal of Ethnic and Migration Studies, 43, 1121-1140.

Bonino, S. (2015) Scottish Muslims Through a Decade of Change: Wounded by the Stigma, Healed by Islam, Rescued by Scotland, Scottish Affairs 24 (1): 78-105.

Curtice, J. and Montagu, I. (2018) Do Scotland and England \& Wales have different views about immigration? ScotCen: British and Scottish Social Attitudes.

Davidson, N., Liinpaa, M., McBride, M. and Virdee, S. (2018) $\quad$ (eds.) No Problem Here: Racism in Scotland. Edinburgh: Luath.

Devine, T. and McCarty, A. (2018) New Scots: Scotland's Immigrant communities since 1945, Edinburgh University Press.

Eichhorn, J.; Paterson, L.; MacInnes, J. and Rosie, M. (2014) Results from the 2014 survey on 14-17 year old persons living in Scotland on the Scottish independence referendum, $A Q$

Emejulu, A. (2013) Being and belonging in Scotland: Exploring the intersection of ethnicity, gender and national identity among Scottish Pakistani groups, Scottish Affairs, 84. 
Fox, J.; Morosanu, L., Szilassy, E. (2012) The racialisation of the new European migration to the UK, Sociology, $46(4)$

Guma, T. and Dafydd Jones, R. (2019) 'Where are we going to go now?' European Union migrants' experiences of hostility, anxiety and (non)belonging during Brexit, Population, Space and Place, 25(1), e2198

Hepburn, E and Rosie, M. (2014) Immigration, Nationalism and Politics in Scotland, in Hepburn, E. and ZapataBarrero, R. (eds.) The Politics of Immigration in Multi-level States, Springer, pp.241-260.

Hepburn, E. (2020) Unhcartered waters: The social and equalities impact of Brexit, Scottish Affairs, 29(2), pp. 141-178.

James, A.and Prout, A. (2014) Constructing and reconstructing childhood: Contemporary issues in the sociological study of childhood, London: Routledge.

Hussain, A. and Miller, W. (2006) Multicultural Nationalism: Islamophobia, Anglophobia and Devolution, Oxford University Press.

Hunter, A. and Meer, N. (2018) Is Scotland different on Race and Migration?, Scottish Affairs, 27(3), 382-387.

McCollum, D.; Nowok, B. and Tindal, S. (2014) Public attitudes towards migration in Scotland: Exceptionality and possible policy implications, Scottish Affairs, 23 (1), 79-102.

McCrone, D. and Bechhofer, F. (2015) Understanding national identity, Cambridge University Press.

National Records of Scotland (2019) Scotland's Population 2018, Edinburgh: NRS.

Sime, D.; Moskal, M.; Tyrrell, N. (2020, Online first) Going Back, Staying Put, Moving On: Brexit and the Future Imaginaries of Central and Eastern European Young People in Britain, Central and Eastern European Migration Review, doi: 10.17467/ceemr.2020.03

Simpson, L. and Smith, A. (2014) Who feels Scottish? National identities and ethnicities in Scotland, Manchester: Centre for the Dynamics of Ethnicity (CODE) Briefing Series.

Tyrrell, N.; Sime, D.; Kelly, C. and McMellon, C. (2019) Belonging in Brexit Britain: Central and Eastern European 1.5 generation young people's experiences, Population, Place and Space, 25(1), e 2205

YouGov (2020) The most important issues facing the country, Available online: https://yougov.co.uk/topics/politics/trackers/the-most-important-issues-facing-the-country 